\title{
A Development of Number Circuit Game Based Learning Strategy to Introduce Numeral Symbols for Children Aged 4-5 Years
}

\author{
1 Rahmi Wardah Ningsih, 2 Slamet Suyanto, ${ }^{3}$ Fauzi Fahmi \\ 1 State University of Yogyakarta, Indonesia \\ 2 State University of Yogyakarta, Indonesia \\ ${ }^{3}$ Islamic State University of North Sumatera, Indonesia
}

\section{ARTICLE \\ INFO}

Artikel History:

Recieved :

$29 / 11 / 2020$

Revised :

15/12/2020

Published:

20/01/2021

\section{Keywords:}

Learning

strategies,

Number circuit

games,

Introduction to

numeral symbols

\section{DOI:}

https://doi.org

/10.46963/mas

h.v4i01.231

\section{Correspondenc \\ e Author: \\ Rahmi Wardah \\ Ningsih \\ Rahmiwardahn \\ @gmail.com}

\begin{abstract}
Understanding the concept of numeral symbols in early childhood is fundamental to understanding mathematical concepts in the future. In view of that, children aged 4-5 years found many problems such as unable to distinguish the form of number symbols, unappropriated learning strategies, and monotonous learning activities. This study aimed to: (1) develop the learning strategies using number circuit games to introduce numeral symbols for 4-5-year-old-children; (2) assess the effectiveness of implementing number circuit games as the learning strategies introducing numeral symbols for 4-5-year-old children. ADDIE with five stages - namely analysis, design, development, implementation, and evaluation - was adopted in this research. The data were analyzed descriptively through qualitative and quantitative techniques. The evidence revealed that: (1) the introduction of numeral symbols for 4-5-year-old children by memorizing and understandings required the implementation of game-based learning strategies; (2) number circuit games which were modified based on the material, the implementation, and the purpose were suitable for children of 4-5 years old; (3) learning strategies using number circuit games to introduce numeral symbols for children of $4-5$ year with p-value. Sig $0.000<0.05$ had revealed that there were significant differences in children's ability in identifying the numeral symbols.
\end{abstract}

How to cite this article:

Ningsih, R. W., Suyanto, S., \& Fahmi, F. (2021). A Development of Number Circuit Game Based Learning Strategy to Introduce Numeral Symbols for Children Aged 4-5 Years. Mitra AshShibyan: Jurnal Pendidikan dan Konseling, 04(01), 47-58. https://doi.org/10.46963/mash.v4i01.231 


\section{INTRODUCTION}

Education is a lifelong process from generation to generation and contains knowledge, life values and life skills. Education is not an instant process, this takes a long time process. Not only occurs in schools, education also takes place in the family, community and surrounding environment. Along with the times, the science of education develops rapidly, which one of gets impact is Early Childhood Education (PAUD). PAUD is one institutional education that is currently getting the attention of the government and society. As of the last 5 years, it was recorded that more than 57,526 villages have received PAUD services either on a formal or non-formal basis. This is inseparable from the government's involvement in the Sustainable Development Goal (SGD), namely 1 village 1 PAUD.

Early Childhood Education is a fundamental education throughout the human life span. PAUD provides a stimulation program to stimulate aspects of child development to develop optimally. The right stimulation is adjusted to the stages of development, the needs of the child, and according to the maturity level of the child's brain. This stimulation is given gradually and continuously. Gradual in this means being carried out from the simplest to things that are more complex and complex.

Stimulation in the PAUD program is carried out to develop aspects of child development. The aspects of early childhood development include physical motor development, language, cognitive, social emotional, religious and moral values, and art. All aspects of child development are stimulated by holistic and integrated learning activities. One of the aspects of development that need attention and get special stimulation is cognitive development.

The term cognitive development is simply defined as the ability to think. The thought process involves the five senses in finding, observing, remembering, and solving problems (Aister, 2017). At the age of $4-5$ years the cognitive stage of the child in Piaget's theory is at the pre-operational stage. At this stage the child understands something based on symbolic thinking and receives information through various sensory stimuli and physical actions taken by the child (Santrock, 1998). The pre-operational stage supports the thinking activities of children aged 4-5 years who understand the environmental reality with symbols as signs. Introducing 
the concept of number symbols is very appropriate at this stage. This is due to the close correlation between the child's ability to understand something with the symbols and the concept of number symbols.

Understanding the concept of number symbols in early childhood is fundamental to understanding mathematical concepts in the future. Not only in academic matters, but in everyday life children will face mathematical concepts, hence the need to emphasize the introduction of number symbols in children. A study revealed that the low understanding of the number symbol concept was caused by the use of conventional, abstract learning strategies, worksheets done by children. At an early age, the concentration of children to focus on daily worksheets is not more than 10 minutes (Friso-van den Bos, Kroesbergen, \& Van Luis, 2014).

The results of a preliminary study on the ability to recognize number symbols in children aged 4-5 years, there are several problems related to the misconception of numbers in children. The mistakes are (1) the child understands the sequence of numbers but is unable to distinguish the form of number symbols from one another, (2) learning strategies that are not in accordance with the purpose of recognizing number symbols, (3) learning activities are monotonous, thus making children bored. This field study is reinforced by research (Aunio, 2006: 45) that teacher performance, social environment, and cultural ethos affect number sense skills, in this case the introduction of number symbols in children.

The ability to identify number symbols is one indicator of number sense. Number sense is a person's sensitivity to numbers (Aunio, 2006). Children with high number sense will quickly recognize and even be able to interpret and do accurate calculations compared to other children (Aunio, 2006). This ability can be enhanced by intense stimulation and habituation from the child's immediate environment. Several studies describe ideas and strategies for developing the ability to recognize number symbols in a child's number sense. One way to improve the child's ability is to improve the quality of teachers. In this case the preschool teacher qualifications are the most important. Teachers do not only focus on teaching numbers but also on providing the necessary environment for children to develop number sense (Kaplan, 2012)

Interesting, creative, and fun activities are needed in introducing the symbols of numbers to children aged $4-5$ years. One of them is in the 
form of a game. Because early childhood is a period of play. The essence of play includes feeling happy, free, and stimulating children to be actively involved (Slamet Suyanto, 2005). Through playing, children are expected to know the symbols of numbers easily. In addition, the introduction of the number symbol also needs to be done with more creative activities so that children don't feel bored.

Teaching and learning activities at the PAUD level cannot be separated from the role of the teacher as the manager of learning in PAUD. This relates to the planning process, the implementation process, and the process of evaluating the learning activities carried out. Qualified teachers are able to manage activities and are able to improve children's abilities and maximize these activities. In the process of designing learning activities, it is related to the learning strategies carried out by the teacher.

The survey conducted by the author regarding the strategies used by the teacher to introduce number symbols is to use the play method and the intensity of the children to see the number symbols installed on the walls of the classroom and the school yard. $90 \%$ of these strategies of habituation are carried out by the teacher and the result is that children are able to recognize several number symbols. The results of this survey have similarities with the research findings of Robet S. Siegler, et al. From the Department of Psychology in Pittsburgh, USA. The research findings reveal that the success of teacher intervention lies in the child's experience of observing a numerical environment. For children, experience with numeric in intervention is able to connect symbolic numbers that children receive in the process of activities in kindergarten / early childhood based on cognitive development theory and data (Siegler \& Ramani, 2011).

Based on the background of the problem, the authors assume to conduct research that leads to teacher intervention to improve the ability to recognize number symbols. Various theoretical studies and the results of previous research became the author's references so that this study led to problem solving of learning strategies based on number circuit games to improve the recognition of number symbols in children aged $4-5$ years. This development research resulted in a learning strategy that was packaged in the form of a game and contained in a compact disk (CD) and completed with a manual for teachers.

50 mitra Ash-Shibyan: Jurnal Pendidikan dan Konseling | Vol. 04, No. 01 (2021) Licensed under CC-BY-SA (c) (1) () 
The numerical circuit is adapted from circuit training, a term for physical motor training and fitness. Scholis (in Paranita, Dhita, \& Fera, 2018) argues about the circuit as follows:

"Circuit training is a method of fitness training that is designed to develop general, all-round physical and cardiovascular fitness".

The above statement states that circuit training is designed to develop general physical abilities and fitness. Generally, circuit training is carried out in physical education programs. The training forms of circuits vary, including traditional or basic elements that are not too complicated, such as the target time for completion of circuit training, fixed weights, red, white, and blue circuits (Whitlow, 2018). The training method on the circuit is used flexibly in various situations, the form of training can be in various patterns, such as circular semicircular patterns, pentagon patterns, squares and two lines and zigzags (Paranita, Dhita; Fera, 2018)

For early childhood use, circuit training is modified into a form of free play and games. Free game in question is free play without being bound by rules and there is no element of competition. One of them is the modification of the number circuit in this study. Number circuit games can be used as free play or as games. If in free play, numbers circuit games can be played without the use of rules and competitions, while in games, number circuit games can be found when played in groups or in teams to compete for speed and accuracy.

Modification of circuit training for early childhood can be adjusted according to the object or development to be improved. For example, modification of the disaster mitigation circuit game to train children's preparedness and preparedness in the event of a natural disaster. In this study, the modification developed was a number circuit game for the introduction of number symbols for children aged 4-5 years.

The number circuit game as a strategy for introducing the symbols of numbers is divided into 3 main parts, namely the opening, the core, and the closing. The three parts of the number circuit game include tasks to introduce number symbols to 4-5 year olds in the form of counting numbers, matching numbers to their number symbols, and sorting numbers 1-10 and vice versa. 
A Development of Number Circuit Game Based Learning Strategy to Introduce Numeral Symbols for Children Aged 4-5 Years

\section{RESEARCH METHOD}

The development of this strategy uses a type of research development or better known as R\&D (Research \& Development). Development research serves to validate existing products and develop products which means updating existing products to be more effective and efficient and easy to use (Sugiono, 2015). This development research aims to develop a learning strategy based on number circuit games to stimulate the ability of children aged 4-5 years to recognize number symbols. Product design starts from analysis, then designs, develops, implements, and the last stage is evaluation. The development research with the product development steps mentioned above is a Dick and Carry development research design, namely the ADDIE model. The ADDIE model is a development research model with the term Analysis, Design, Development, Implementation, and Evaluation (Branch, 2009).

\section{RESULT AND DISCUSSION}

In accordance with the stages of development research with the ADDIE model, namely Analysis, Design, Development, Implementation, and Evaluation. The first stage, namely needs analysis, was carried out in 3 kindergartens with a total of 6 sources. Then the design and development is carried out designing the form of a video game book and $\mathrm{CD}$ and validating the design with experts and practitioners.

Table 1. Result of Validation of Material anda Media Expert

\begin{tabular}{lclc}
\hline \multicolumn{2}{c}{ Material Expert } & \multicolumn{2}{c}{ Media Expert } \\
\hline \multicolumn{1}{c}{ Aspects } & Mean & \multicolumn{1}{c}{ Aspects } & Mean \\
\hline Suistability of Material & 80 & Content Quality & 95 \\
\hline \multirow{2}{*}{ Beneficial for Children } & 80 & Functional Quality & 95 \\
\cline { 3 - 4 } & & Technical Quality & 94.4 \\
\hline Mean Total & $\mathbf{8 0}$ & Mean Total & $\mathbf{9 4 . 8 3}$ \\
\hline Category & Very Worthy & Category & Very Worthy \\
\hline
\end{tabular}

Based on table 1, the results of material and media expert validation are obtained with the category "very feasible. In addition, there are several improvements and revisions to the material, namely instruments related to the assessment rubric. Whereas for media experts, product improvement is in the form of manual content so that it is added to the theory behind the learning strategy based on the number circuit game. Furthermore, the researchers conducted a reliability test to 
determine the consistency and consistency of the assessor's item on the introduction of number symbols for children aged 4-5 years. The reliability test used is the split half reliability test using SPSS 20.0 software.

Table 2. Result Instrument Realibity Test

\begin{tabular}{ccc}
\hline Item & Split Half & Decision \\
\hline 10 & 0.936 & Reliable \\
\hline
\end{tabular}

Based on table 11, it is known that the split half reliability test is 0.936 , which is greater than 0.70 , so it can be concluded that the items in the instrument used to assess the introduction of number symbols for children aged 4-5 years are reliable.

After revising the materials and number circuit game products, the next step is to implement a number circuit based learning strategy that is declared feasible by expert judgment. The application of this game involved 3 kindergartens, namely TK Bim Bim Cha with 13 children and 2 teachers, Baitur-Rahmah TK / RA with 23 children and 2 teachers, and 25 children from TK Tunas Wisata with 2 teachers. The application is divided into 2 parts, namely small-scale and large-scale trials. The small-scale trial was carried out at Bim Bim Cha Kindergarten with a total of 13 children and was carried out in 4 meetings. The first meeting, assessing the child's ability to recognize number symbols without the use of number circuit games. The second meeting introduced the number circuit game as one of the learning strategies that the teacher will practice and do in the kindergarten, while the 3rd and 4th meetings are a complete implementation of the number circuit game from beginning to end. Smallscale trials resulted in user questionnaire assessments, in this case the teacher.

Table 3. Teacher Assesment Mean

\begin{tabular}{|c|c|c|c|c|c|}
\hline \multirow{2}{*}{ Aspects } & \multicolumn{4}{|c|}{ Teacher } & \multirow{2}{*}{ Mean } \\
\hline & 1 & 2 & 3 & 4 & \\
\hline Suistability of Material & 72.8 & 78.5 & 82.8 & 77.1 & 95 \\
\hline Content Quality & 65 & 85 & 80 & 85 & 78.75 \\
\hline Functional Quality & 80 & 75 & 90 & 65 & 77.5 \\
\hline Technical Quality & 87.2 & 80 & 87.2 & 87.2 & 85.4 \\
\hline \multicolumn{5}{|c|}{ Mean Total } & 94.83 \\
\hline \multicolumn{5}{|c|}{ Category } & Very Worthy \\
\hline
\end{tabular}


Based on the table above, the average for the assessment of material suitability aspects is 77.8 , while for the aspects of content quality, functional quality, and technical quality each is $78.75 ; 77.5$; and 85.4 so that the total mean score on the validation questionnaire has the criteria of "very feasible" (see table 3). In addition to assessing the number circuit game, the researcher also calculated the pretest and posttest scores. This assessment aims to determine the ability to recognize children's number symbols before and after implementing a learning strategy based on a number circuit game.

Table 4. Result Pretest and Posttest Test a Small Scale the Ability to Know the Symbol Numbers of Children Age 4-5 Years

\begin{tabular}{lcc}
\hline \multirow{2}{*}{ Results } & $\begin{array}{c}\text { The Ability of Recognizing the } \\
\text { Numeral Symbols }\end{array}$ \\
\cline { 2 - 3 } & Pretest & Posttest \\
\hline Number of Children & 13 & 13 \\
\hline The highest score & 34 & 36 \\
\hline Lowest value & 20 & 23 \\
\hline Average & $\mathbf{2 . 6}$ & $\mathbf{2 . 9}$ \\
\hline Standard score & $\mathbf{6 5}$ & $\mathbf{7 3 . 7}$ \\
\hline
\end{tabular}

Based on table 4 above, the number of children who were assessed for their ability to recognize the symbol was 13 . Of the 13 children observed, the highest scores were obtained before and after the number circuit based learning strategy was applied, namely 34 and 36 respectively. values obtained were 20 and 23 . The lowest scores after the number circuit game were applied increased compared to before the game-based strategy was applied. Analysis of pretest and posttest data, it was found that the average value of the ability to recognize number symbols for children aged 4-5 years was lower, namely 2.6 compared to the results after applying the learning strategy with number circuit games, namely 2.9 with standard scores of 65 and 73.7 . The quantitative data analysis described above concluded that in the small-scale test the application of learning strategies through number circuit games had an effect on the ability to recognize number symbols in children aged $4-5$ years.

Furthermore, the effectiveness of learning strategies based on number circuit games on the introduction of number symbols for children aged 4-5 years was analyzed with the help of SPSS 20.0, namely the Mann Whitney test. The results of different tests were carried out with the same 
treatment strategy in 2 different TK A classes to determine whether there was a difference in the mean value of the ability to recognize number symbols after treatment.

Table 5. Output Mann-Whitney Test

\begin{tabular}{ccccc}
\multicolumn{5}{c}{ Ranks } \\
\hline & Kelompok & N & Mean Rank & Sum of Ranks \\
\hline \multirow{3}{*}{ Hasil } & A1 & 24 & 13.56 & 325.50 \\
\cline { 2 - 6 } & A2 & 24 & 35.44 & 850.50 \\
\cline { 2 - 5 } & Total & $\mathbf{4 8}$ & & \\
\hline
\end{tabular}

From the output of table 14, the mean value of the results for Class A1 is presented with a mean rank of 13.56 and in class A2 is 35.44. Then testing the hypothesis with the Mann-Whitney test can be seen in the table below as follows:

Table 6. Hypothesis Test Mann-Whitney

\begin{tabular}{lr}
\multicolumn{2}{c}{ Test Statistics a } \\
\hline Mann-Whitney U & \multicolumn{1}{c}{ Hasil } \\
\hline Wilcoxon W & 25.500 \\
\hline Asymp. Sig. (2-tailed & 325.500 \\
\hline
\end{tabular}

a. Grouping variable

Sourced in table 6 obtained by Asymp. Sig. 0,000. This means that the P-value $<0.05$, so it can be concluded that Ha is accepted and Ho is rejected, namely that there is a difference in the ability to recognize number symbols for children aged 4-5 years with the use of learning strategies based on number circuit games.

The final stage of the ADDIE design development research is the evaluation stage. The evaluation phase aims to determine the efficiency and effectiveness of the learning strategy descriptively in the form of input, criticism, and suggestions from the validators and practitioners (teachers). Evaluation is divided into 2 types, namely formative and summative evaluation. The formative evaluation process has been carried out during the needs analysis, design, and development stages before the implementation process is held.

This evaluation is in the form of written and unwritten input from supervisors, validators, and fellow students. Then summative evaluation assesses the overall learning strategy based on the number circuit game in

mitra Ash-Shibyan: Jurnal Pendidikan dan Konseling | Vol. 04, No. 01 (2021) 55 
the form of the effectiveness of the resulting product. The effectiveness of using a learning strategy based on the number circuit game is explained in the effectiveness test using the time series equivalent design and analyzed by the Mann-Whitney test in the decision of the research hypothesis.

\section{CONCLUSION}

The use of number circuit learning strategies is one way to channel excess children's energy and play actively using their motor muscles, however extra supervision is needed at each post to avoid injuries to children. The teacher can apply the concept of the number circuit game for the introduction of number symbols in several treatments and add posts as needed. There is also a need for variations per post circuit game and level of difficulty for children's cognitive processes in terms of recognition of number symbols in order to increase optimally. The dissemination stage in this development research was limited in cost, time, and energy so that the implementation of the dissemination was only in the form of product submission to several research kindergartens. The product of this development research is expected to be a solution to the problems faced by teachers in introducing number symbols to children aged 4-5 years.

\section{BIBLIOGRAPHY}

Aistear. (2017). Learning and developing through play. The Early Childhood Curriculum Framework, Vol. I 53-70.

Aunio, P. (2006). Number sense in young children international group differences and an intervention programme for children with low and average performance. Helsinki (10-30). https://doi.org/10.1311/j.21516952.1981.tbXZC1513.x

Branch, R. M. (2009). Instructional design: The ADDIE approach. INJETSE, (2-45). https:// doi.org/10.1007/978-0-387-09506-6

Friso-van, B. I., Kroesbergen, E. H., \& Van Louis, J. E. H. (2014). Number sense in kindergarten children: Factor structure and working memory predictors. Learning and Individual Differences Journal, 33, 23-29. https:// doi.org/10.1016/j.lindif.2014.05.003

Kaplan, H. A. (2012). Prospective preschool teachers ideas for developing the number sense of children. Procedia-Social and Behavioral Sciences, 46(2004), 3870-3874. https://doi.org/10.1016/j.sbspro.2012.06.163

Paranita, D. , \& Fera, D. (2018). pengembangan permainan sirkuit mitigasi bencana gempa bumi untuk meningkatkan self-awareness anak usia dini. Jurnal Caksana-Pendidikan Anak Usia Dini, 1(2), 172-187

Santrock, J.W. (2007). Perkembangan anak. (Terjemahan oleh Mila Rhmawati \& Anna Kuswanti). Jakarta : Erlangga. (Edisi asli diterbitkan tahun 1996 oleh Brown \& Benchmark Publishers.

56 mitra Ash-Shibyan: Jurnal Pendidikan dan Konseling | Vol. 04, No. 01 (2021) Licensed under CC-BY-SA (c) (1) (2) 
Siegler, R. S., \& Ramani, G. B. (2011). Improving low-income children's number sense. space, time and number in the brain. Elsevier Inc, Vol. 1, (4-7). https:/ / doi.org/10.1016/B978-0-12-385948-8.00021-9

Sugioyono. (2015). Metode penelitian kuantitatif, kualitatif, dan RED. Bandung: Alfabeta.

Suyanto, S. (2005). Dasar-dasar pendidikan anak usia dini. Yogyakarta: Hikayat Publishing

Whitlow, G. (2018). Elementary circuit training. Journal of Health, Physical Education, Recreation, 39(5), 26-27. https://doi.org/10.1080/00221473.1968.10611718 
A Development of Number Circuit Game Based Learning Strategy to Introduce Numeral Symbols for Children Aged 4-5 Years

This page is intentionally left blank

58 mitra Ash-Shibyan: Jurnal Pendidikan dan Konseling | Vol. 04, No. 01 (2021) Licensed under CC-BY-SA (c) (1) () 